\title{
Microbial Succession Within an Anaerobic Sequencing Batch Biofilm Reactor (ASBBR) Treating Cane Vinasse at $\mathbf{5 5}^{\circ} \mathrm{C}$
}

\author{
Maria Magdalena Ferreira Ribas ${ }^{1 *}$, Fabio Alexandre Chinalia ${ }^{2}$, Eloisa Pozzi ${ }^{3}$ and Eugenio \\ Foresti $^{3}$ \\ ${ }^{1}$ Universidade Estadual de Maringá; Campus do Arenito; Rodovia PR 482 km 45; 87820-000; Cidade Gaúcha - PR \\ - Brasil. ${ }^{2}$ National University of Ireland; University Road.; Galway - Ireland. ${ }^{3}$ Hidráulica e Saneamento; Escola de \\ Engenharia de São Carlos; Universidade de São Paulo; Av. Trabalhador São Carlense, 400; C. P.: 359; 13560 - \\ 970; São Carlos - SP - Brasil
}

\begin{abstract}
The aim of this work was to investigate the anaerobic biomass formation capable of treating vinasse from the production of sugar cane alcohol, which was evolved within an anaerobic sequencing batch biofilm reactor $(A S B B R)$ as immobilized biomass on cubes of polyurethane foam at the temperature of $55^{\circ} C$. The reactor was inoculated with mesophilic granular sludge originally treating poultry slaughterhouse wastewater. The evolution of the biofilm in the polyurethane foam matrices was assessed during seven experimental phases which were thus characterized by the changes in the organic matter concentrations as COD (1.0 to 20.0 g/L). Biomass characterization proceeded with the examination of sludge samples under optical and scanning electron microscopy. The reactor showed high microbial morphological diversity along the trial. The predominance of Methanosaeta-like cells was observed up to the organic load of $2.5 \mathrm{gCOD/L.d}$. On the other hand, Methanosarcinalike microorganisms were the predominant archaeal population within the foam matrices at high organic loading ratios above $3.3 \mathrm{gCOD/L.d}$. This was suggested to be associated to a higher specific rate of acetate consumption by the later organisms.
\end{abstract}

Key words: anaerobic digestion, adaptation phase, wastewater, sugar cane, biofilm, microbiology

\section{INTRODUCTION}

The quantity and quality of the wastewater generated in the production of ethanol using sugar cane as primarily substrate is one of the largest environmental problems in Brazil. Brazilian production of ethanol was estimated as 15.1 billion liters per year (Agrianual, 2005), and approximately 12 to 14 liters of vinasse is generated with each liter of produced ethanol. The high volume is not the only immediate problem; this wastewater also shows high chemical oxygen demand (COD) values, reaching up to $100 \mathrm{~g} / \mathrm{L}$ (Wilkie et al., 2000). The wastewater is disposed at high temperatures, because vinasse temperature is close to $90^{\circ} \mathrm{C}$ after the distillation process, but it may fall to $60^{\circ} \mathrm{C}$ in its course to the treatment system. This temperature makes biodegradation a difficult and/or expensive process once a cooling step would be necessary for applying the

\footnotetext{
Author for correspondence: m2fribas@yahoo.com.br
} 
conventional biological treatments. On the other hand, considerable attention has been paid towards the development of new strategies for the biological treatment, such as anaerobic reactors aiming at the conversion of organic matter into biogas (Kennedy et al., 1991). For instance, the anaerobic bath reactor has simple operation regarding instrumentation, and it is also an important tool for the fundamental research focusing several important aspects of anaerobic biodegradation (Zaiat et al., 2001). Biomass retention within such reactor results from the growth of microorganisms attached to a support material or from self-immobilization process such as granules that remain in the interstices of the polyurethane matrices by the formation of biofilm (Varesche et al., 1997). It has been reported that the immobilization process enhances the thermostability of the system by providing an extra biomass buffer for a sudden change in temperature (van Lier, 1996). The largest problem regarding the applicability of thermophilic reactors is the availability of thermophylic anaerobic sludge for the reactor's inoculation and start-up procedure (Ahring, 1994). Therefore, the choice of a mesophilic sludge with high microbial diversity is crucial to ensure the development of a thermophilic biomass. Chen (1983) evaluated the metabolic adaptation of mesophilic anaerobic sludge to thermophilic temperatures and from that only $9 \%$ were thermophiles and $1 \%$ were obligate thermophiles from the total bacterial population in the mesophilic reactor.

Assumptions of the presence of certain types of microorganisms by optical microscopy are uncertain, but according to Sarti et al. (2006), apart from chemical analysis, microscopic microbiological observations are an important approach available for monitoring the changes in the microbial populations of a biofilm. This knowledge is useful for making it possible to understand some of the metabolic advantages and/or disadvantages of such systems during anaerobic treatment which are commonly assessed by organic matter removal efficiencies.

The aim of this work was to observe the microbial evolution of a thermophilic biofilm formed within an anaerobic sequencing batch reactor treating vinasse at $55^{\circ} \mathrm{C}$ by optical and scanning electron microscopy. The seeding sludge was obtained from an UASB (upflow anaerobic sludge blanket) reactor treating poultry slaughterhouse wastewater at ambient temperature.

\section{MATERIALS AND METHODS}

The bench scale ASBBR had total and working volumes of 7.2 liters and 3.5 liters, respectively. It was composed by two concentric cylindrical flasks with internal diameters of 19 and $22 \mathrm{~cm}$, both with $25 \mathrm{~cm}$ of height. The space between the external and internal walls was filled with warm water continuously recycled from an external bath kept at $55 \pm 2^{\circ} \mathrm{C}$. The reactor was filled with polyurethane foam cubes of $1 \mathrm{~cm}$ (apparent density of $23 \mathrm{~kg} / \mathrm{m}^{3}$ and $95 \%$ porosity) for biomass immobilization. The foams were placed in a perforated cylindrical basket (mesh $0.5 \mathrm{~cm}$ ) of stainless steel with external and internal diameters of $17.5 \mathrm{~cm}$ and $7.0 \mathrm{~cm}$, respectively, and height of $18 \mathrm{~cm}$. This basket was placed in the reactor. Mixing was achieved using a mechanical mixer axis of 2 impellers fixed in the void space in the center of the stainless steel basket. The experimental set-up used is shown in Figure 1. This mixer was operated at 300 rotations per minute. The cubic foam matrices were inoculated with mesophilic granular anaerobic sludge $(36 \mathrm{mg}$ of total volatile solids/g of sludge) taken from an UASB reactor treating poultry slaughterhouse wastewater at ambient temperature $\left(\sim 25^{\circ} \mathrm{C}\right)$. The initial temperature of the operation of the reactor was $35^{\circ} \mathrm{C}$. But, the temperature was raised abruptly from $35^{\circ} \mathrm{C}$ to $55^{\circ} \mathrm{C}$ after 21 days of inoculation.

Filling and discharge were performed by diaphragmatic pumps controlled by the timers. The vinasse was collected from the exit disposal duct of the industry and stored in a refrigerator $\left(\sim 4^{\circ} \mathrm{C}\right)$. The feeding medium supplied to the experimental reactor was diluted vinasse and dilution ratios were carried out according to the required organic concentration of each experimental phase. This medium was enriched with a solution of mineral salts, (phosphorus, calcium and iron) trace metals (nickel, cobalt and selenium) and $\mathrm{NaHCO}_{3}$. The $\mathrm{HCO}_{3}{ }^{-} / \mathrm{COD}$ ratio ranged from 0.2 to 1.2 . The applied organic loading ratios (OLR) varied from 1.0 and $6.6 \mathrm{gCOD} / \mathrm{L} . \mathrm{d}$ (Table 1). The evolution and population dynamics was based on the microscopic observations of the morphotypes present in the biomass along with the operation of the reactor. In each phase, samples of polyurethane foam cubes were taken from the top, middle and bottom of the reactor's basket in vertical profiles. They were subjected to scanning electron and optical microscopy examinations. 


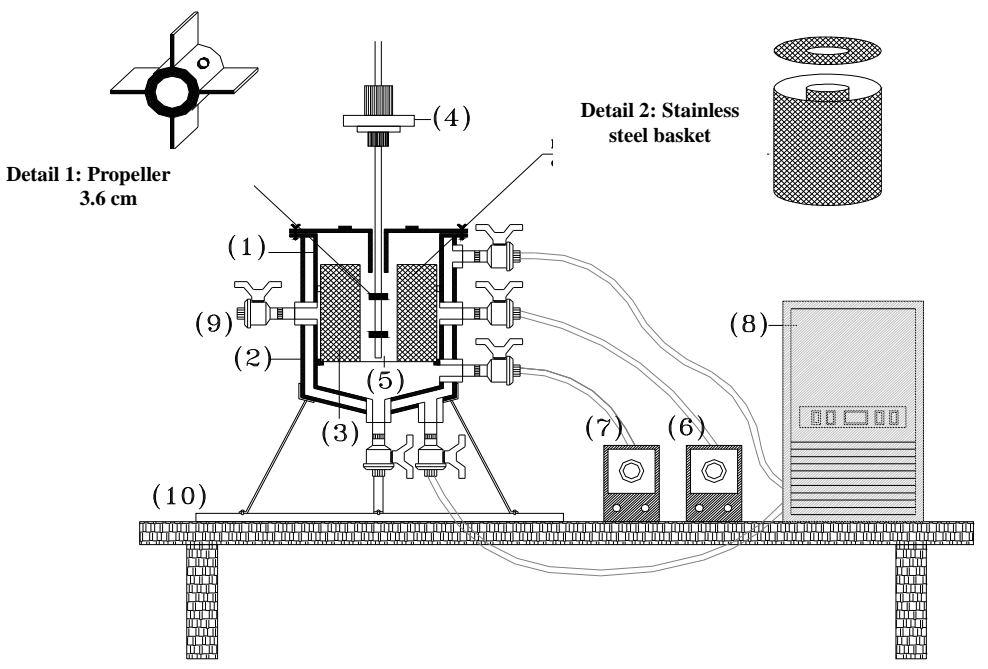

Figure 1 - Diagrammatic representation of the ASBBR reactor (Lapa, 2003): (1) Anaerobic sequencing batch biofilm reactor, (2) warm water jacket, (3) stainless steel basket, (4) Engine of the mechanical propellers, (5) propellers, (6) feeding pump, (7) discharging pump, (8) heat exchangers, (9) sampler, (10) bench.

The cubes were macerated to remove the adhered biomass and each sample was stamped at previously prepared slides containing $2 \%$ agaragar layer. Observations were made using an Olympus BX-60 equipped with contrast-phase and fluorescence, measured by ultraviolet light excitation, and documentation was made using "Optronics" camera and software "Image Pro Plus" (4.1). Methanosarcina-like cells can be tentatively identified by fluorescence microscopy, because they have some unique coenzymes, F420 and F350, which turn them fluorescents. The morphological incidence of observed cells in the random chosen microscopic fields was classified as frequent (more than 40\%), less frequent (between 10 and 40\%), rare (less than 10\%) and absent (not observed).

Samples for scanning electron microscopy (SEM) were subjected to the technique developed by Nation (1983) and adapted to bacterial biofilms by Araujo (1995). The sample preparation procedures are also described in Lima et al. (2005). Briefly, the samples were fixed in $0.1 \mathrm{M}$ phosphate buffer $(\mathrm{pH} \mathrm{7.3)} \mathrm{containing} \mathrm{2.5 \%} \mathrm{glutaraldehyde} \mathrm{for} 12 \mathrm{~h}$ at $4^{\circ} \mathrm{C}$. After fixation, the samples were rinsed three times in $0.1 \mathrm{M}$ phosphate buffer ( $\mathrm{pH} 7.3$ ) and dehydrated gradually after successive immersions in ethanol solutions of increasing concentrations (50, 70, 80, 90 and 95\%). Each rinsing and dehydrating step lasted $10 \mathrm{~min}$. The samples were washed three times in 100\% ethanol before immersion in hexamethyldisilazane for 30 seconds. The drying step was completed by holding the samples at $60^{\circ} \mathrm{C}$ for $2 \mathrm{~h}$. The particles were then coated with gold powder and stuck onto microscope slides with silver glue. SEM analyses were performed using a Zeiss model DSM-960 digital scanning microscope.

Microbial diversity was also assessed by carrying out the polymerase chain reaction and denaturing gradient gel electrophoresis (PCR/DGGE) technique according to Muyzer (1999) with bacterial and archaeal primers used by Nübel et al. (1996) and Großkopf et al. (1998), respectively. This technique was only applied for samples from the inoculum and for samples from the last experimental phase VII considering the biomass was already adapted the thermophilic temperature treating vinasse.

After the DGGE analysis of the individual biofilm samples, the individual DGGE profiles were compared to each other by using the pair-wise similarity coefficient $C s$, determined as follows: $C s=[2 j /(a+b)]^{*} 100$, where $a$ was the number of DGGE bands in inoculum, $b$ was the number of DGGE bands in biomass from the phase VII, and $j$ was the number of common DGGE bands. Two identical DGGE profiles have a Cs value of $100 \%$, 
and two completely different profiles have a $C s$ value of 0\% (Gillan et al., 1998).

Phenol and organic acids concentrations were quantified by gas chromatography (Moraes et al., 2001).

The performance of the ASBBR was evaluated by monitoring the influent and effluent characteristics. Chemical oxygen demand (COD), total solids (TS), total volatile solids (TVS) and $\mathrm{pH}$ were determined according to the Standard Methods for the Examinations of Water and
Wastewater (1995). Bicarbonate alkalinity (BA) was according to DiLallo and Albertson (1961), modified by Ripley et al. (1986). Total volatile acids (TVA) were evaluated according to DiLallo and Albertson (1961). Sulfate was analyzed twice in the crude vinasse. The nitrogen compounds were determined only in the vinasse. In the phase VII, sulfate and sulfite temporal profiles were obtained by analyzing samples from the internal liquid of the reactor.

Table 1 - Experimental phases in the thermophilic ASBBR.

\begin{tabular}{ccccc}
\hline Phase & Operation days $(\mathbf{d})$ & $\mathbf{T}_{\mathbf{c}}(\mathbf{d}) *$ & OLR $(\mathbf{g} / \mathbf{L} . \mathbf{d})$ & HCO $_{\mathbf{3}}{ }^{-} / \mathbf{C O D}$ \\
\hline Start up & 50 & $1.0-2.0$ & $0.5-1.2$ & $0-1.2$ \\
I & 08 & 1.0 & 1.0 & 1.2 \\
II & 22 & 1.0 & 2.5 & 0.8 \\
III & 35 & 1.5 & 3.3 & 0.8 \\
IV & 13 & 3.0 & 3.3 & 0.6 \\
V & 111 & 6.0 & 3.3 & 0.6 \\
VI & 109 & $1.5-3.0$ & $3.3-6.6$ & 0.4 \\
VII & 43 & 2.0 & 5.0 & 0.6 \\
\hline
\end{tabular}

$* \mathbf{T}_{\mathbf{c}}$ - Time of cycle.

\section{RESULTS AND DISCUSSION}

An average the COD value for the crude vinasse was $51 \mathrm{~g} / \mathrm{L}$ ( \pm 8.5 of standard deviation). Sulfate, total potassium and total nitrogen concentrations were $1.80( \pm 0.15) \mathrm{g} \mathrm{S}-\mathrm{SO}_{4}{ }^{-2} / \mathrm{L}, 6.1( \pm 5.6) \mathrm{g}$ $\mathrm{K}_{\text {total }} / \mathrm{L}$ and $2.4( \pm 3.0) \mathrm{g} \mathrm{N}_{\text {total }} / \mathrm{L}$, respectively, at a $\mathrm{pH}$ of 4.6. The results, however, varied considerably according to the specific constitution of different sugar cane crops.

The phase of biomass adaptation lasted 39 cycles (corresponding to 50 days of operation). The operational cycles were of $24 \mathrm{~h}$ until $28^{\text {th }}$ cycle; after, it was increased to $48 \mathrm{~h}$ until the $39^{\text {th }}$ cycle. This strategy was adopted to guarantee enough residence time for organic acid degradation and methane production. In this phase, the organic loading rate was increased from 0.5 to $1.2 \mathrm{gCOD} / \mathrm{L} . \mathrm{d}$ and alkalinity was supplemented at the ratio of $1.2 \mathrm{HCO}_{3}{ }^{-} / \mathrm{COD}$. Until the $21^{\text {st }}$ cycle, the reactor was operated at temperature of $35^{\circ} \mathrm{C}$. From this cycle, the temperature was abruptly raised to $55^{\circ} \mathrm{C}$.
COD removal was $43( \pm 7.9), 72( \pm 8.7), 68( \pm$ $19.2), 78( \pm 9.0), 55$ ( \pm 10.0$), 46( \pm 19.2)$ and $70 \%$ $( \pm 5.5)$ with initial organic matter concentrations of $0.8,2.5,5.5,13.5,24.0,12$ and $9.6 \mathrm{gCOD} / \mathrm{L}$ in the phases I to VII, respectively. In the first phase, the low efficiency of COD removal (43\%) could still be related to the acclimation of the biomass to the feeding wastewater. In the phases III (5.5 $\mathrm{gCOD} / \mathrm{L})$ and $\mathrm{V}(24.0 \mathrm{gCOD} / \mathrm{L})$, the decrease in the organic matter removal efficiency seemed to be correlated more with the initial organic matter concentrations applied to the reactor than with the volumetric organic loading rate that was maintained at $3.3 \mathrm{~g} / \mathrm{L} . \mathrm{d}$ in both the phases. A decrease of COD removal efficiency was observed in phase $\mathrm{V}(55 \%)$ and an increase in concentration of total organic acids (3455 mgHAc/L). The accumulation of such acids could result in the collapse of the system. Therefore, as a precaution, the organic matter loading ratio was reduced to 12 and $9.6 \mathrm{gCOD} / \mathrm{L}$ in the following phases (VI and VII, respectively). The mean values and respective standard deviations of variables monitored during the experiment are shown in the Table 2. 
Table 2 - Mean values of some monitored variables during operation of thermophilic ASBBR (391 d).

\begin{tabular}{|c|c|c|c|c|c|c|c|}
\hline \multirow{2}{*}{ Phases } & \multicolumn{2}{|c|}{$\mathrm{BA}\left(\mathrm{mg} \mathrm{CaCO}_{3} / \mathrm{L}\right)$} & \multicolumn{2}{|c|}{ TVA (mg HAc/L) } & \multicolumn{2}{|c|}{$\operatorname{COD}(\mathrm{g} / \mathrm{L})^{*}$} & \multirow{2}{*}{$\mathrm{COD}_{\text {removal }}(\%)$} \\
\hline & Influent & Effluent & Influent & Effluent & Influent & Effluent & \\
\hline Adaptation & $571 \pm 332$ & $369 \pm 309$ & $76 \pm 64$ & $308 \pm 114$ & $1.2 \pm 0.1$ & $0.7 \pm 0.2$ & $37.2 \pm 5.5$ \\
\hline I & $893 \pm 78$ & $959 \pm 98$ & $214 \pm 73$ & $224 \pm 59$ & $0.8 \pm 0.04$ & $0.5 \pm 0.05$ & $42.8 \pm 7.9$ \\
\hline II & $1453 \pm 54$ & $1761 \pm 77$ & $410 \pm 65$ & $219 \pm 95$ & $2.5 \pm 0.3$ & $0.7 \pm 0.1$ & $72.3 \pm 8.7$ \\
\hline III & $2408 \pm 572$ & $2737 \pm 733$ & $708 \pm 181$ & $640 \pm 267$ & $5.5 \pm 1.3$ & $1.6 \pm 0.7$ & $68.0 \pm 19.2$ \\
\hline IV & $3785 \pm 72$ & $5818 \pm 204$ & $1812 \pm 299$ & $844 \pm 272$ & $13.5 \pm 2.0$ & $2.8 \pm 0.9$ & $78.0 \pm 9.0$ \\
\hline $\mathrm{V}$ & $5657 \pm 1085$ & $5847 \pm 1303$ & $3554 \pm 790$ & $3435 \pm 939$ & $24.0 \pm 3.3$ & $10.7 \pm 2.1$ & $54.6 \pm 10.0$ \\
\hline VI & $2170 \pm 686$ & $2066 \pm 661$ & $1566 \pm 245$ & $2400 \pm 468$ & $12.0 \pm 3.9$ & $5.9 \pm 1.3$ & $46.0 \pm 19.2$ \\
\hline VII & $2877 \pm 150$ & $4573 \pm 808$ & $1719 \pm 40$ & $881 \pm 604$ & $9.58 \pm 2.8$ & $2.8 \pm 0.6$ & $69.6 \pm 5.5$ \\
\hline
\end{tabular}

*COD - total influent COD and centrifuged (at 2000 rotations per minute) effluent COD.

The physiological acclimation of the biomass along the experiment was observed by the progressive increment on the organic matter removal efficiencies (43 to 78\%) recorded from phase I to IV. On the other hand, it was possible that the amount of organic matter in the influent of the phase V (20 gCOD/L) imposed a shock load into the system. Progressive increases in the concentrations of volatile acids were observed in phases III, IV and V (Table 2). Despite that, the bicarbonate alkalinity generated in the reactor was kept constant even after the reduction in the bicarbonate amendments in the substrate from 0.8 (phase III) to $0.6 \mathrm{HCO}_{3}{ }^{-} / \mathrm{COD}$ (phases IV and V). Furthermore, all the results obtained in phases I, II, III and IV pointed out at a specific adaptation of the mesophilic sludge to the thermophilic condition. High diversity of microbial morphologies was observed throughout the experiments. The optical microscopy was used to estimate the incidence and frequency of observed microbial morphologies and to score them as predominant, frequent, less frequent and rare (Table 3).

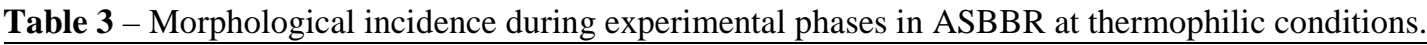

\begin{tabular}{|c|c|c|c|c|c|c|c|c|c|c|c|c|c|c|c|c|c|c|}
\hline \multirow{3}{*}{ Morphologies } & \multicolumn{18}{|c|}{ Experimental phases - Sample points* } \\
\hline & \multicolumn{3}{|c|}{ I } & \multicolumn{3}{|c|}{ II } & \multicolumn{3}{|c|}{ III } & \multicolumn{3}{|c|}{ IV } & \multicolumn{3}{|c|}{$\mathbf{V}$} & \multicolumn{3}{|c|}{ VII } \\
\hline & $\mathbf{T}$ & $\mathbf{M}$ & $\mathbf{B}$ & $\mathbf{T}$ & $\mathbf{M}$ & $\mathbf{B}$ & $\mathbf{T}$ & $\mathbf{M}$ & $\mathbf{B}$ & $\mathbf{T}$ & $\mathbf{M}$ & $\mathbf{B}$ & $\mathbf{T}$ & $\mathbf{M}$ & $\mathbf{B}$ & $\mathbf{T}$ & $\mathbf{M}$ & $\mathbf{B}$ \\
\hline \multicolumn{19}{|l|}{ Bactéria Domain } \\
\hline Coccus & - & - & + & +++ & + & + & - & + & - & - & - & + & - & +++ & +++ & - & + & + \\
\hline Rods & +++ & +++ & +++ & +++ & $\begin{array}{c}++ \\
+\end{array}$ & +++ & ++ & ++ & +++ & +++ & +++ & +++ & $\begin{array}{c}++ \\
+\end{array}$ & +++ & +++ & +++ & $\begin{array}{c}++ \\
+\end{array}$ & $\begin{array}{c}++ \\
+\end{array}$ \\
\hline Curve rod & - & ++ & ++ & - & - & ++ & + & + & + & - & ++ & ++ & ++ & +++ & +++ & ++ & ++ & ++ \\
\hline $\begin{array}{l}\text { Filaments } \\
\text { Archaea Domain }\end{array}$ & - & + & + & - & - & ++ & + & + & ++ & +++ & +++ & +++ & ++ & ++ & + & + & ++ & ++ \\
\hline Methanosaeta-like & +++ & +++ & +++ & +++ & ++ & +++ & ++ & +++ & +++ & +++ & +++ & +++ & + & ++ & + & + & + & + \\
\hline $\begin{array}{l}\text { Methanosarcina- } \\
\text { like }\end{array}$ & - & +++ & +++ & - & $\begin{array}{c}++ \\
+\end{array}$ & ++ & +++ & +++ & +++ & ++ & +++ & +++ & + & +++ & +++ & +++ & $\begin{array}{c}++ \\
+\end{array}$ & $\begin{array}{c}++ \\
+\end{array}$ \\
\hline Fluorescent rods & - & + & +++ & - & - & +++ & +++ & +++ & +++ & - & - & - & $\begin{array}{c}++ \\
+\end{array}$ & +++ & +++ & +++ & $\begin{array}{c}++ \\
+\end{array}$ & $\begin{array}{c}++ \\
+\end{array}$ \\
\hline Others & & & & & & & & & & & & & & & & & & \\
\hline S. cereavisiae-like & +++ & +++ & +++ & +++ & $\begin{array}{c}++ \\
+\end{array}$ & +++ & +++ & +++ & +++ & ++ & +++ & +++ & $\begin{array}{c}++ \\
+\end{array}$ & +++ & +++ & ++ & ++ & ++ \\
\hline
\end{tabular}

*Sample points in the reactor: $\mathrm{T}-$ top, $\mathrm{M}-$ middle, $\mathrm{B}-$ bottom.

Incidence: (+++) Frequent, (++) Less frequent, (+) Rare, (-) Not observed.

The inoculum taken from UASB reactor showed several morphotypes of rods (curve, fine, coccoid, grouped coccoid) as cells (Fig. 2a and 2c), fine filaments which were similar to Methanosaeta-like cells (Fig. 2c: arrow) and morphotypes resembling Methanosarcine-like cells (Fig. 2b).
The optical microscopy showed that few morphological differences were observed in the microbial populations colonizing the vertical profile of the reactor's basket (top to bottom). It was also observed that the micro-granules mechanically retained within the polyurethane 
foam were neither different regarding their size nor their microbial morphotypes. These observations could be a resultant of the hydrodynamic characteristics of ASBBR, which has been commonly defined as being of complete mixed reactor and, therefore, as a result it reduced the effect of substrate stratification and mass transference within the biofilm.

During the experimental phases, rods of several morphotypes and filaments were frequently observed (Fig. 2c), which were generally associated with the hydrolysis and fermentation phases of the anaerobic degradation pathway. The predominance Methanosaeta-like cells (Fig. 4d: arrow) was detected at the initial phases I and II with only a few incidences of Methanosarcina-like cells. However, the occurrence of these methanogens of the genus Methanosarcina increased in the subsequent phases, with the increment of the vinasse concentrations starting from the phase III with $5 \mathrm{gCOD} / \mathrm{L}$ and OLR of 3.3 g/L.d.

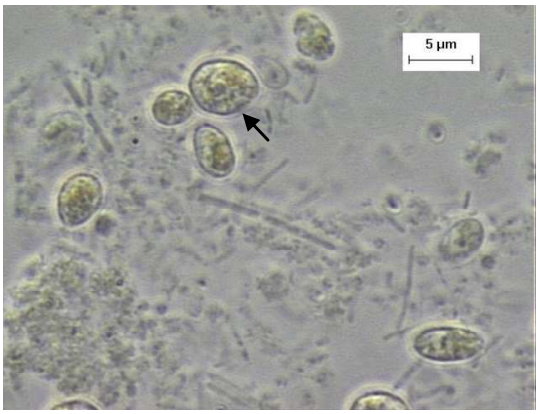

(A)

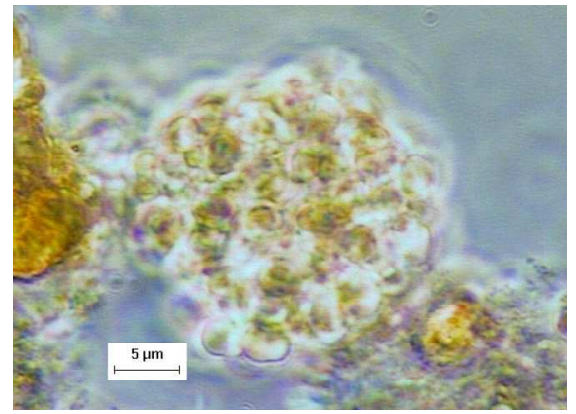

(B)

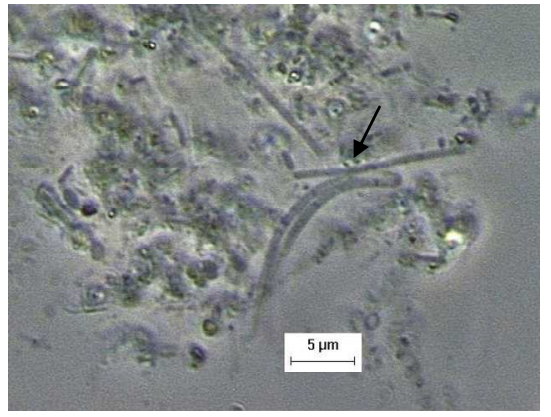

(C)

Figure 2 - Observed morphologies by optical microscopy (1500X): (a) diversity of rods and yeast S. cerevisiae - like: arrow, (b) Methanosarcine -like cells and, in detail, the same cell in fluorescence, (c) biomass and cells Methanosaeta -like (arrow), rods and cocci.

Methanosarcina have higher growth rate ( $\left.\mu_{\text {maximum }}\right)$, of 1.27 to $2.04 \mathrm{~d}^{-1}$, than Methanosaeta $\left(0.48\right.$ to $\left.0.72 \mathrm{~d}^{-1}\right)$ with acetate like carbon resource in termophilic conditions $\left(55^{\circ} \mathrm{C}\right)$ (van Lier, 1993; van Lier, 1995). The acetotrophic methanogens are present in the samples with high organic loading, which generally resulted in high acetate concentrations (Ahring, 1994).

In samples collected after six hours of a cycle, about 70,150 and $300 \mathrm{mg} / \mathrm{L}$ of acetic acid was detected in the phases I, II and III, respectively. These values were totally decreased until the end of the cycles.

During the experiments, abundant frequency of yeasts-like cells, especially at the reactor's top was also recorded. The presence of oxygen in such region might have played an important role affecting the vertical distribution of such organisms within the reactor. Another reason would be the capacity of the yeasts to float due to the presence of oil droplets within the cells. It is important to point out that yeast cells might have been present in the wastewater and have not contributed to important degradation role during the vinasse anaerobic treatment. Such an assumption could be made because the observed yeast cells resembled Saccharomyces cereavisiae (arrows of the Fig. 2a and 4e) which were common during ethanol production using a fermentative process. It was possible that the yeast-like cells were inactive at $55^{\circ} \mathrm{C}$ and also accounting for the low likelihood of intact survival after the distillation process.

The occurrence of curve rods was also observed that could be sulfate reducing bacteria (SRB).

Dessulfovibrio-like cells appeared starting from the phase III with $5 \mathrm{gCOD} / \mathrm{L}$ and $0.16 \mathrm{~g} \mathrm{~S}^{-\mathrm{SO}_{4}}{ }^{2-} / \mathrm{L}$. The organic matter of the influent may follow degradation by two distinct metabolic routes in anaerobic conditions: methanogenesis or sulfate reduction. When sulfate is available, it can be used as final electron acceptor for anaerobic respiration causing organic matter degradation without the production of methane. Methanogenesis is only favored in this competition when organic matter and sulfate ratio is higher than $0.67 \mathrm{COD} / \mathrm{SO}_{4}{ }^{2-}$ 
(Hulshoff et al., 1998). For instance, in phase V (with $20.0 \mathrm{~g} \mathrm{COD} / \mathrm{L}$ and $0.65 \mathrm{~g} \mathrm{~S}^{-S^{2-}} / \mathrm{L}$ ), the $\mathrm{COD} / \mathrm{SO}_{4}{ }^{2-}$ ratio was 31.0 , therefore, amply favorable for methanogenesis. In the previous experiments (phases I and II), the presence of SRB-like cells was not observed, in spite of their reproducing high rates when compared to the methanogens. This happened probably because the inoculum had high density of methanogenic organisms, and, thus, they dominated in the system. But when the organic concentration in substrate was higher (starting from the phase III with $5 \mathrm{gCOD} / \mathrm{L}$ ), methanogenic organisms could have had a reduction in their activity, once it was observed that the average COD removal declined from $72 \%$ (phase II with $2.5 \mathrm{gCOD} / \mathrm{L}$ ) to $68 \%$ in the phase III (Table 2) and SBR-like morphotypes were more frequently observed. Therefore, the SRB might have overcome the disadvantage of its low density in the inoculation when high contents of organic matter were applied provoking an organic shock, especially in the initial hours of the cycles. Then, the SBR-like cells were observed in the next phases. To prove this hypothesis, samples of the effluent of two different cycles were collected in the last experimental phase for sulfate and sulfite analyses (Fig. 3) in the first five hours. The total elimination of the sulfate ion was observed after fourth hour. It is well known that sulfite ions are products of the SBR metabolism in the organic matter degradation (Postgate, 1984).

Figure $4 \mathrm{c}$ shows the morphology of curve rod observed under scanning electronic microscopy. In the phase VII, the fine and small rods (Fig. 4f) observed could be hydrogen-utilizing methanogens (Ahring, 1994), for instance, Methanobacterium. Some of those morphotypes were fluorescent in epifluorescence microscopy.

Phenol values were detected from 1 to $7 \mathrm{mg} / \mathrm{L}$ along all the experimental phases. Phenol was totally degraded during the operating cycles at each batch. This could be due to high diversity of rods and coccus.

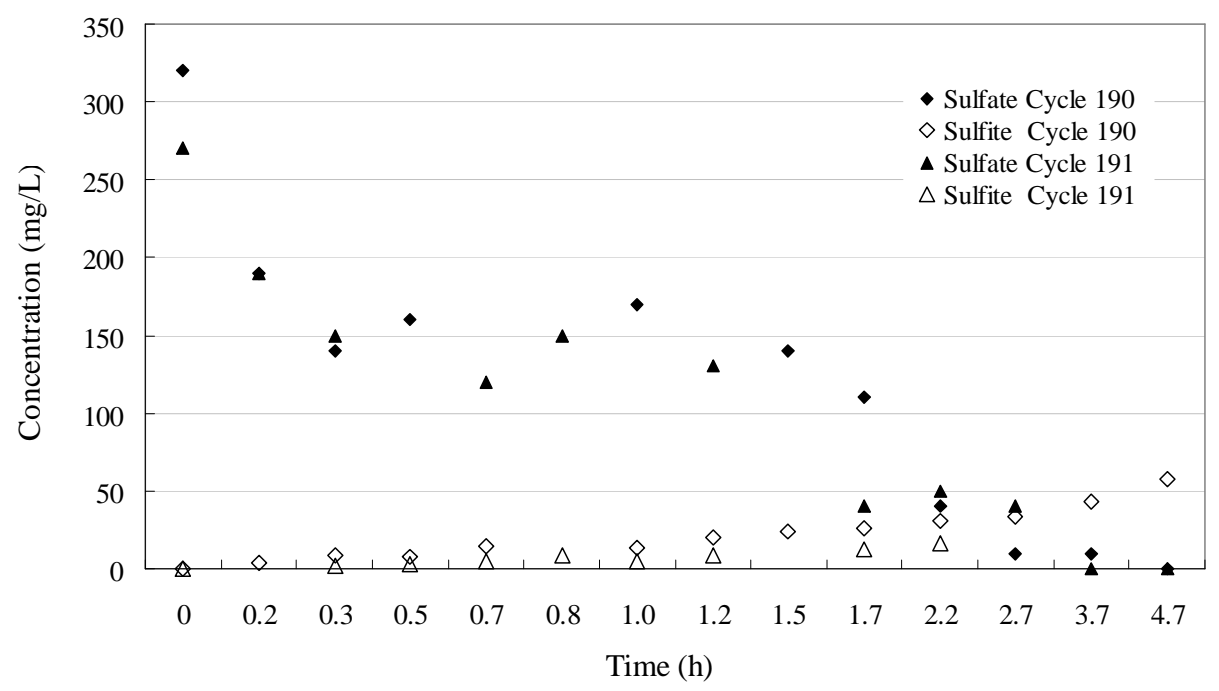

Figure 3 - Profile of sulfate and sulfite along the cycles 190 and 191 of the phase VII.

DGGE-profiling showed considerable variation regarding bacterial and archaeal diversity between the mesophilic inoculum and the established thermophilic biomass from the phase VII with a similarity coefficient of $0.005 \%$ both for the bacterial and archaeal populations. This meant that the populations changed almost completely from the inoculation to the end of operation (Fig. 5). The biomass developed in the sludge of the phase VII was different from the inoculum because all the environmental conditions were altered. The microorganisms that were capable to adapt simultaneously to the residue and the high temperature grew, which also demonstrated the versatility of the biomass used as inoculum.

Therefore, it could be concluded that the mesophilic sludge used as inoculum in the ASBBR was capable to generate a degrading thermophilic biomass for treating vinasse. The microbial biomass evolved in the polyurethane foam showed in the initial phases (I, II and III) the predominance of morphologies similar to the 
archaeal Methanosaeta-like, several morphotypes of rods, yeast-like cells and some cells resembling Methanosarcina spp. From phase IV onwards, Methanosarcina-like cells became more frequent allied with fluorescent rods that were tentatively identified as hydrogenotrophic methanogens. The choice of the inoculum might also have been a determinant factor affecting the competition between the methanogenesis and sulfate-reducing metabolism. Although the organic loads applied to the biomass were expected to be assimilated by the methanogenic population, the results indicated that high initial COD concentration could have had a pronounced effect on the performance of the sequencing batch reactor. Therefore, the biomass metabolic potential for COD removal from vinasse would depend on a previous evaluation of the microbial populations colonizing the reactor.

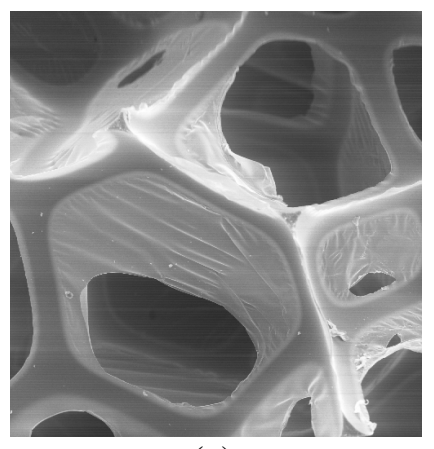

(a)

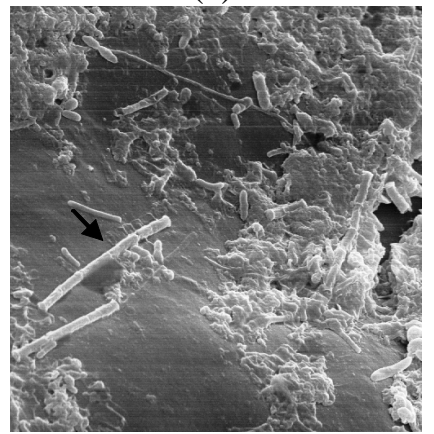

(d)

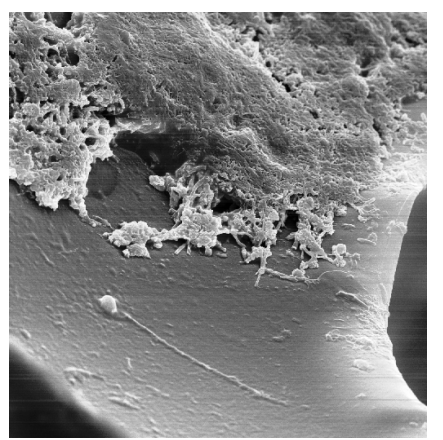

(b)

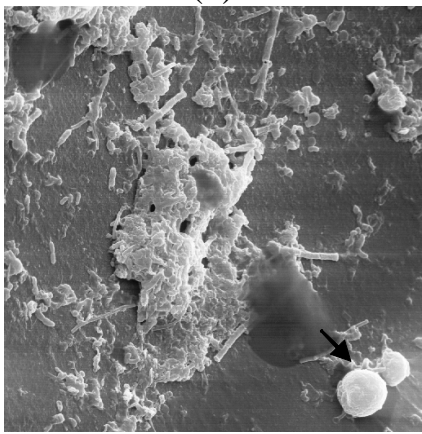

(e)

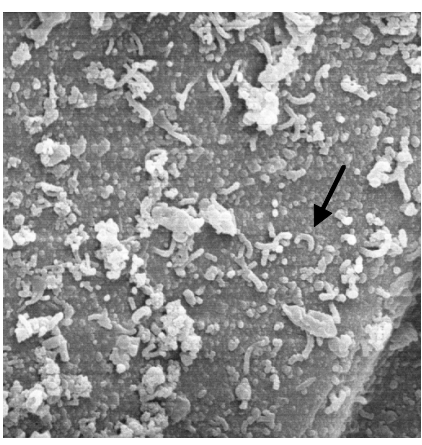

(c)

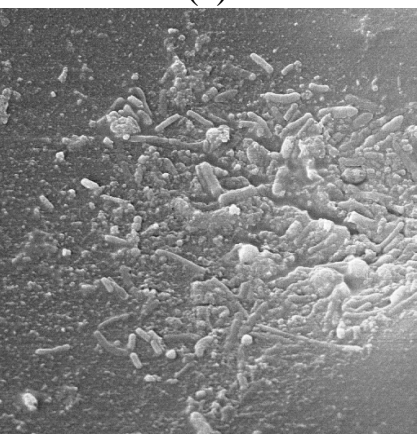

(f)

Figure 4 - Scanning electronic microscopy: (a) polyurethane foam for biomass immobilization (100X), (b) biomass superficial adherence to the support (1000X), (c) several types of rods and curve rod (arrow) (3000X), (d) rods and Methanosaeta -like (arrow) (3000X), (e) Methanosaeta -like cells and yeast (arrow), (f) similar to hydrogenutilizing methanogens rods cells (3000X).

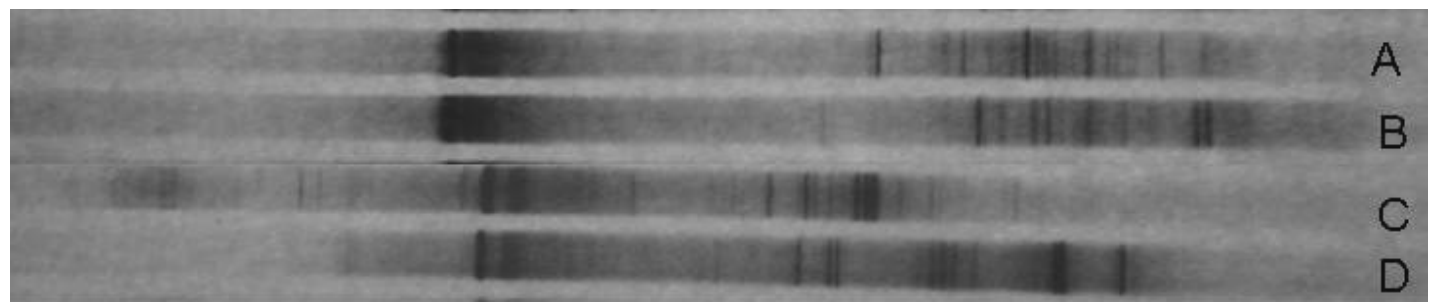

Figure 5 - Bacterial and archaeal diversity as assessed by DGGE. (A) Bacterial DGGE-profiling of the mesophilic inoculum, (B) Bacterial DGGE-profiling of the biomass sampled in phase VII, (C) Archaeal DGGE-profiling of the mesophilic inoculum and (D) Archaeal DGGE-profiling of the biomass sampled in the phase VII. 


\section{ACKNOWLEDGEMENTS}

The authors acknowledge the financial support received for this work from FAPESP- Fundação de Amparo a Pesquisa do Estado de São Paulo given to the Thematic Project n. 2001-05489-0, Brazil, and the grant received from CAPES Coordenação de Aperfeiçoamento de Pessoal de Nível Superior, Brazil.

\section{RESUMO}

Este trabalho investigou a formação de um biofilme anaeróbio capaz de tratar vinhaça da produção de álcool de cana-de-açúcar, que evoluiu dentro de um reator operado em bateladas sequienciais com biofilme (ASBBR) tendo a biomassa imobilizada em cubos de espuma de poliuretano na temperatura de $55^{\circ} \mathrm{C}$. O reator foi inoculado com lodo granular mesofílico tratando água residuária de abatedouro de aves. A evolução do biofilme nas matrizes de espuma de poliuretano foi observada durante sete fases experimentais que foram caracterizadas por mudanças nas concentrações de matéria orgânica como DQO (1,0 a 20,0 g/L). A caracterização da biomassa foi feita por exames de amostras do lodo em microscopia ótica e eletrônica de varredura. O reator apresentou grande diversidade de morfologias ao longo do experimento. A predominância de células como Methanosaeta foram observadas até a carga orgânica de 2,5 gDQO/L.d. Por outro lado, microrganismos como Methanosarcina foram a população arquéia predominante nas matrizes de espuma em taxas de carregamento orgânico acima de 3,3 gDQO/L.d. Este fato pode estar relacionado com maior taxa de utilização específica de acetato por esses microrganismos.

\section{REFERENCES}

Agrianual (2005), Anuário da agricultura brasileira. $10^{\text {th }}$ ed. São Paulo, FNP Consultoria, Brasil, pp. 270272. (in Portuguese)

Ahring, B.K. (1994), Status on science and application of thermophilic anaerobic digestion. Water Science and Technology, 30 (12), 241-249.
Araújo, J. C. (1994), Acompanhamento da evolução do biofilme e caracterização química e biológica em reator de leito fluidificado tratando esgoto sanitário sintético. MSc. Thesis, Escola de Engenharia de São Carlos, Universidade de São Paulo, São Carlos, SP, Brasil. (in Portuguese)

Chen, M. (1983), Adaptation of mesophilic anaerobic sewage fermentor populations to thermophilic temperatures. Applied and Environmental Microbiology, 45 (4), 1271-1276.

Dilallo, R. and Alberton, O. E. (1961), Volatile acids by direct titration. Journal of Water Pollution Control Federation, 33 (4), 356-356.

Gillan, D. C., Speksnijder, A. G. C. L., Zwart, G., Ridder, C. (1998), Genetic diversity of the biofilm covering Montacuta feruginosa (Mollusca, Bivalvia) as evaluated by denaturing gradient gem electrophoresis analysis and cloning of PCRamplified gene fragments coding for 16S rRNA. Applied and Environmental Microbiology, 64 (9), 3464-3472.

Großkopf, R., Janssen, P. H., Liesack, W. (1998), Diversity and structure of the methanogenic community in anoxic rice paddy soil microcosms as examined by cultivation and direct $16 \mathrm{~S}$ rRNA gene sequence retrieval, Applied and Environmental Microbiology, 64, 960-969.

Kennedy, K. J., Sanchez, W. A., Hamoda, M. F., Droste, R.L. (1991), Performance of anaerobic sludge blanket sequencing batch reactors. Research Journal of Water Pollution Control Federation, 63, 75-83.

Hulshoff, P. L., Lens, P. N. L., Stams, A. J. M., Lettinga, G. (1998), Anaerobic treatment of sulphaterich watewaters. Biodegradation 9, 213-224.

Lapa, K. R. (2003), Avaliação de desempenho do reator anaeróbio em batelada seqüencial (ASBR), contendo biomassa imobilizada em pedra pome, para tratamento de esgoto sanitário. MSc. Thesis, Escola de Engenharia de São Carlos, 106p. Universidade de São Paulo, São Carlos, SP, Brasil. (in Portuguese)

Lima, C. A. A., Ribeiro, R., Foresti, E., Zaiat, M. (2005), Morphological study of biomass during the start-up period of a fixed-bed anaerobic reactor treating domestic sewage. Brazilian Archives of Biology and Technology, 48 (5), 841-849.

Moraes, E. de M., Foresti, E., Zaiat, M., Adorno, M. A. T. (2001), Determinação de ácidos voláteis por cromatografia gasosa em efluentes de reatores anaeróbios. In: Chernicharo, C.A.L. (coord.). Póstratamento de efluentes de reatores anaeróbios: aspectos metodológicos. Belo Horizonte: Prosab. p. 35-39.

Muyzer, G. (1999), DGGE/TGGE a method for identifying genes from natural ecosystems. Curr. Opin. Microbiol. 2, 317-322. 
Nation, J. L. (1983), A new method using hexamethyldilazane for preparation of soft tissues for scanning electron microscopy. Stain Technology, 58, 347-351.

Nübel, U., Engelen, B., Felske, A., Snaidr, J,. Wieshuber, A., Amann, R. I., Ludwig, W., Backhaus, H. (1996), Sequence heterogeneities of genes ncoding $16 \mathrm{~S}$ rRNAs in Paenibacillus polymyxa detected by temperature gradient gel electrophoresis, Journal of Bacteriology. 178, 5636-5643.

Postgate, J. R. (1984), The sulphate-reducing bacteria, 2 ed., Cambridge: Cambridge University Press.

Ripley, L. E., Boyle, W. C. and Converse, J. C. (1986), Improved alkalimetric monitoring anaerobic digestion of high-strenght wastes. Journal of water pollution control federation, 58, 406-411.

Sarti, A., Pozzi, E., Chinalia, F.A., Zaiat, M., Foresti, E. (2006), The performance of an anaerobic sequencing batch biofilm reactor treating domestic sewage colonized by anoxygenic phototrophic bacteria. Chemosphere, 62, 1437-1443.

Standard Methods for the Examination of Water and Wastewater (1995), American Public Health Association / American Water Works Association / Water Environment Federation, $19^{\text {th }}$ ed. Washington, DC, USA.

Van Lier, J. B. (1993), Depuración anaerobia de águas residuales, Actas del seminario digestión anaerobia de aguas residuales, Valladolid, Spain, 5, 1-12. (in Spanish)

Van Lier, J. B. (1995), Thernophilic anaerobic wastewater treatment; temperature aspects and process stability. Thesis. Wageningen University, $181 \mathrm{p}$.

Van Lier, J. B. (1996), Limitations of thermophilic anaerobic wastewater treatment and the consequences for process design, Antonie van Leeuwenhoek, 69, 114.

Varesche, M. B. A., Zaiat, M., Vieira, L. G. T., Vazoller, R. F., Foresti, E. (1997), Microbial colonization of polyurethane foam matrices in horizontal-flow anaerobic immobilized-sludge reactor. Applied Microbiology and Biotechnology, 48, 534-538.

Wilkie, A. C., Riedesel, K. J. and Owens, J. M. (2000), Stillage characterization and anaerobic treatment of ethanol stillage from conventional and cellulosic feedstocks. Biomass and Bioenergy, 19, 63 - 102.

Zaiat, M., Rodrigues, J. A. D., Ratusznei, S. M., Camargo, E. F. M., Borzani, W. (2001), Anaerobic sequencing batch reactors for wastewater treatment: A developing technology. Applied Microbiology and Biotechnology, 55: 29 - 35
Received: September 27, 2006; Revised: July 20, 2007; Accepted: December 10, 2008. 